\title{
Technological Catch-up and Knowledge Sourcing of Latecomers from Emerging Economies
}

Jaeyong Song, Seoul National University, Korea

\section{Introduction}

In most technological sectors, firms in developed countries such as the US, Europe, and Japan have accumulated technological capabilities for many years and are now recognized as global technology leaders. Firms in emerging economies are behind these incumbent leaders in developed countries. Due to the size of their head start, some economists have argued that it is almost impossible for latecomers in emerging economies to catch up with incumbent industry leaders in knowledge-intensive industries such as semiconductors, biotechnology, or computer software. However, some laggards in emerging economies such as Samsung Electronics have recently caught up with incumbent leaders even in technology-intensive industries such as the memory chip industry. How do laggards from emerging economies catch up with industry incumbents in such technology-intensive industries? Investigation of the catch-up strategies utilized by these firms is worthwhile for researchers in the fields of strategy and international management. In particular, researchers should examine how and under what conditions laggards from emerging economies can catch up with incumbent leaders. In this article, I suggest promising areas for future empirical research on this increasingly visible and important phenomenon in international business.

\section{Increase in Technological Catch-up of Latecomers from Emerging Economies}

In recent decades, major firms in such East Asian countries as Korea, Taiwan, and China have rapidly developed their own technologi-

Figure 1. Utility Patents Granted by the USPTO from 1963 to 2009 (China, Korea, Taiwan)

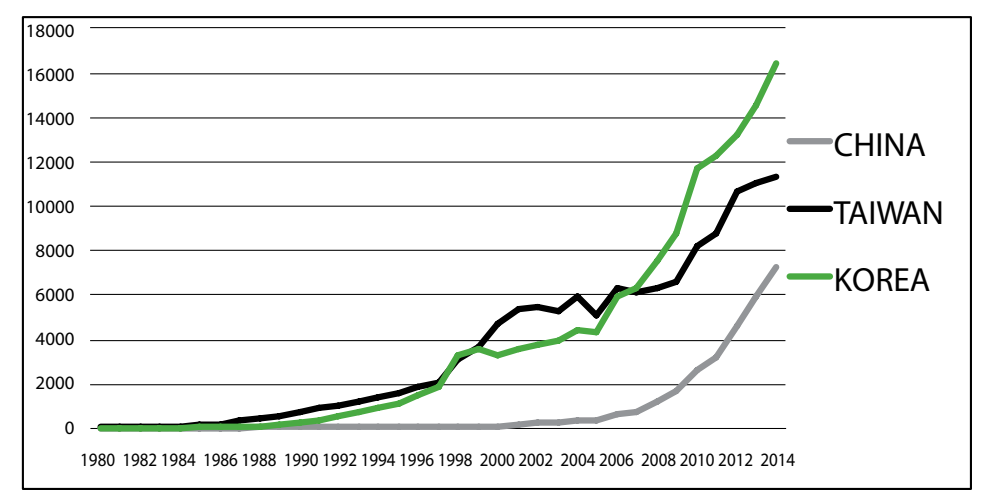

cal capabilities. As powerful proof, patent records from the US Patent and Trademark Office (USPTO) show that the number of patents has increased exponentially since the late 1980s in Korea and Taiwan and since the turn of the $21^{\text {st }}$ century in the case of China (see Figure 1). Figure 2 shows that in the semiconductor industry, Korea recorded exponential growth in the number of patents since the late 1980s. This figure shows that in terms of patents in the semiconductor industry, Korea and Taiwan has outperformed the UK, France, and Germany since the mid-1990s. More importantly, unlike the exponential growth in the number of semiconductor patents in the 1990s in Korea, only a slight increase was observed in these countries during the same period.

Over time, some Asian companies (e.g., Samsung, LG, and Hyundai-Kia Motors in Korea, MediaTek and AUO in Taiwan, and Huawei in China) have shown that under certain conditions, technological laggards can overcome disadvantages and use latecomer-specific advantages to catch up with incumbent, first-mover firms in developed countries. In particular, Korea's Samsung Electronics has been the global leader in the memory chip business since 1993, just 10 years after its initial entry into the industry. In 2006 and 2014, Samsung ranked second in terms of patent registration in the U.S., surpassed only by IBM. In 2015, the Samsung name finally reached the top of the USPTO patent ranking.

\section{Boundary Conditions for Technological Catch-up of Laggards}

I propose that in future research on this topic of technological catchup of latecomers from emerging economies, boundary conditions should be investigated. The technological environment, which may also be called the technological regime, offers the most important boundary condition for technological catch-up of laggards. This term refers to economic factors that govern the trajectory of technological advancement and innovation. The technological environment affects how patterns of innovation and technological catch-up differ by industry. Nelson and Winter (1982) showed that technological environments, including technological opportunities, cumulativeness, and appropriability of knowledge, have major effects on the intensity of innovation, the degree of industrial concentration, and the rate of entry in any industry. Understanding of how the technological environment influences technological catch-up activities of laggards requires identification of the technological conditions that favor laggards while undermining incumbent leaders. 
Figure 2. Comparison of Korean Semiconductor Patents with Those of Major Advanced Countries (registration counts in the USPTO)

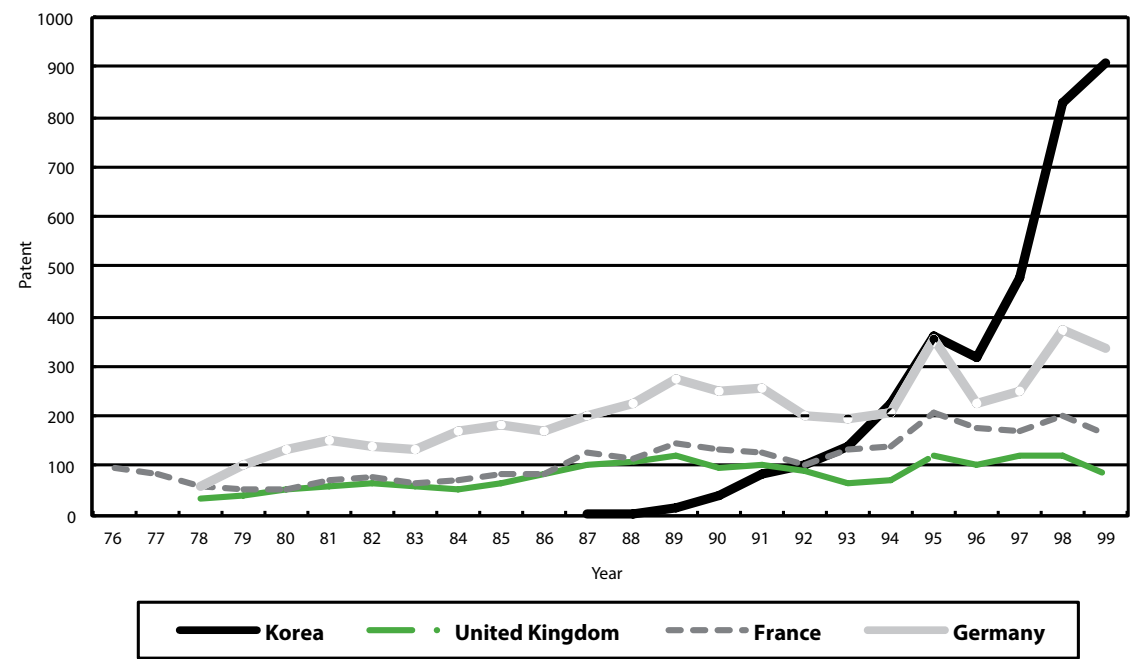

Prior literature defines a latecomer as a firm that is a late entrant to an industry that is initially resource-poor, and that regards catching up as its primary goal (Mathews, 2002). Extant studies on entry order identified many advantages for first movers. These competitive advantages for incumbents are important market barriers to laggards (latecomers), making catch-up tremendously difficult. Thus, latecomers in emerging economies should seek technological environments that are more favorable for catch-up with incumbent leaders. Research has shown that latecomers are more successful when they seize emerging opportunities within their technological environments.

In some cases, a paradigm shift in the technological environment disrupts existing technological trajectories that have provided advantages to market incumbents. In my earlier work examining Samsung (Khanna, Song, \& Lee, 2011; Song \& Lee, 2014), I highlighted the case of Samsung's catch-up with Sony in television technology and sales when the electronics industry underwent a paradigm shift from analog to digital technology. To catch up with Sony, Samsung concentrated its innovation efforts on digital television early on, whereas Sony, the incumbent leader, stuck to analog for too long, partly due to a success trap or inertia and partly due to the fear of cannibalization. In addition to technological opportunities, other aspects of technological regimes such as appropriability, cumulativeness, or technology life cycles can influence latecomers' catch-up probability. The technological regime influenced innovation activities in emerging economies and chances of catching up successfully (Lee \& Lim, 2001).

While the technological environment serves as an important boundary condition for catch-up, firm-level factors such as learning strategy can also be important boundary conditions for catch-up. In the catch-up process, laggards follow moving targets, as technological leaders are always moving on to new innovations (Nelson \& Winter 1982). Thus, to succeed in catch-up, they must develop appropriate strategies for time-compressed learning so that they can move faster than industry incumbents. They should also choose an appropriate learning target in the catch-up process, depending on their absorptive capacity and the size of the technology gap with incumbent leaders.

\section{Knowledge Sourcing Modes and Technological Catch-up}

In the technological catch-up process, laggard firms from emerging economies can source knowledge through diverse modes (Song, 2014). In the early stage of technological catch-up, imitation is crucial (Kim, 1997); many laggards from emerging economies tend to acquire technology through reverse engineering, OEM, or licensing. Some laggards may go one step further by sourcing external knowledge through strategic alliances, including joint ventures or even M\&As. Foreign direct investment in the form of strategic equity investment can be an efficient vehicle for sourcing country-specific, firmembodied technological knowledge (Shan \& Song, 1997).

Other laggard firms that lack sufficient absorptive capacity may source knowledge by scouting experienced engineers from incumbent firms. State-of-the-art technologies often comprise tacit knowledge built through experience and learning-by-doing. Valuable tacit know-how is embodied in individuals; thus, without the mobility of engineers, it cannot be easily transferred across firms. As opposed to technology licensing, as a result of which laggards often end up with outdated technologies, mobile engineers can bring not only tacit know-how but also ability to develop it further. In my article (Song, Almeida, \& Wu, 2003), I showed "learning-by-hiring" is a useful strategy by which latecomers gain access to advanced knowledge.

To catch up with incumbent leaders, laggards from emerging economies should allocate resources to in-house $R \& D$ investments as well (Kim, 1997). Striking a fine balance between imitation and innovation is critical for the technological catch-up of latecomers. Setting up overseas R\&D operations in the geographical center of innovation can be an effective strategy for laggards from emerging economies to catch up with incumbent leaders. My research found that overseas $R \& D$ labs are more effective for knowledge sourcing and transfer across the borders than alliances or licensing (Almeida, Song, \& Grant, 2003). My research also demonstrated the importance of both technological capabilities of overseas R\&D labs and external embeddedness in local scientific and engineering communities in knowledge sourcing from host countries (Song, Asakawa, \& Chu, 2011).

Samsung's remarkable catch-up in the semiconductor industry illustrates the importance of setting up an overseas R\&D lab in the geographical center of innovation (Song \& Lee, 2014). Since its entry into the DRAM business, Samsung has used multiple modes of technology sourcing - technology licensing, internal development, technology-seeking foreign direct investment, and recruitment of experienced 
engineers - simultaneously. Recognizing its lack of a prior knowledge base in the DRAM business, Samsung set up its "SSI" R\&D lab in the Silicon Valley in 1983 to coincide with its entry into the DRAM business. Samsung then scouted experienced engineers who had worked for U.S. companies. About $80 \%$ of SSI engineers were ethnic Korean engineers, as an important objective of setting up the R\&D lab in the Silicon Valley was to harness the abilities of engineers who wanted to stay in the U.S. In a peak year, SSI hired 260 engineers in the Silicon Valley.

From the beginning, SSI made attempts not only to absorb and assimilate licensed technologies for mass production in Korea, but also to build new knowledge. Just ten months after developing 64K DRAM chips based on licensed technology from Micron Technology, SSI developed its own design for 256K DRAMs, which was rated superior to the licensed design. In addition, these overseas R\&D labs served as training grounds for Korean engineers who were educated and trained in Korea. They also served as information scanning outposts to acquire the latest technical information, as well as to monitor and identify important new technological trends that were taking place in the Silicon Valley or the U.S. in general.

\section{Conclusion}

In this article, I called for more systematic and rigorous empirical investigation of technological catch-up of latecomers from emerging economies. Though some prior studies offered good insights into how technological regimes affect catch-up strategies in developing countries, most were conducted at the country or industry level. Various case studies document the ways in which Asian companies have been able to close the technological gap effectively (e.g., Khanna et al., 2011). However, it is difficult to generalize findings based on these studies, as they focus on specific, usually successful, cases. Few studies have investigated this phenomenon empirically at the firm level, using large-sample firm-level data. As a result, our understanding of why some laggards manage to catch up successfully while others fail to do so is still limited. To catch up with industry incumbents, latecomers from emerging economies should identify environmental conditions that favor laggards while undermining incumbent leaders. Thus, I propose that we should examine under what conditions latecomers from emerging economies are more likely to catch up. To catch up with industry incumbents, they may need to rely on multiple modes of technology sourcing. Thus, I also propose that we should investigate what channels or modes of entry latecomers from emerging economies should rely on for knowledge sourcing and innovation and how they should change the mix of channels/modes in different stages of catch-up.

\section{References}

Almeida, P., Song, J. Y., \& Grant, R. 2002. Cross-border knowledge building by firms, alliances, and markets. Organization Science, 13(2): 147-161.
Khanna, T., Song, J. Y., \& Lee, K. M. 2011. The rise of Samsung's paradox. Harvard Business Review, July-August: 142-147.

Kim, L. 1997. Imitation to innovation: The dynamics of Korea's technological learning. Boston: Harvard Business School Press.

Lee, K., \& Lim, C. 2001. Technological regimes, catching-up and leapfrogging: Findings from the Korean industries. Research Policy, 30(3): 459-483.

Mathews, J. A. 2002. Competitive advantages of the latecomer firm: A resource-based account of industrial catch-up strategies. Asia Pacific Journal of Management, 19(4): 467-488.

Nelson, R. R., \& Winter, S. G. 1982. An evolutionary theory of economic change. Cambridge, MA: Harvard University Press.

Shan, W., \& Song, J. Y. 1997. Foreign direct investment and the sources of technological advantage: Evidence from the biotechnology industry. Journal of International Business Studies, 28 (2): 267-284.

Song, J. Y. 2014. Subsidiary absorptive capacity and knowledge transfer within multinational corporations. Journal of International Business Studies, 45 (1): $73-84$.

Song, J. Y., Almeida, P., \&Wu, G. 2003. Learning by hiring: When is mobility more likely to facilitate interfirm knowledge transfer? Management Science, 49(4): 351-365.

Song, J. Y., Asakawa, K., \& Chu, Y. 2011. What determines knowledge sourcing from host locations of overseas R\&D operations? A study of global R\&D activities of Japanese multinationals. Research Policy, 40(3): 380-390.

Song, J. Y., \& Lee, K. M. 2014. The Samsung way. New York: McGraw Hill.

Jaeyong Song (jsong@snu.ac.kr) is AMOREPACIFIC professor at Seoul National University and a JIBS area editor. His Ph.D. is from Wharton and he was a professor at Columbia. He won Best Dissertation Awards from AOM's IM Division and the European International Business Association. He published articles in Management Science, Harvard Business Review, Strategic Management Journal, Organization Science, Journal of Economics \& Management Strategy, Journal of Management, JIBS, California Management Review, and Research Policy. 